\title{
Marionetki Cypriana Norwida a ich polsko- i anglojęzyczne wykonanie przez Czesława Niemena
}

\author{
Agata Brajerska-Mazur \\ Uniwersytet Marii Curie Skłodowskiej w Lublinie \\ a.bm@poczta.umcs.lublin.pl
}

\begin{abstract}
Streszczenie
Niemenowska anglojęzyczna interpretacja „Marionetek” Cypriana Norwida różni się zarówno od polskojęzycznego wykonania utworu przez muzyka w 1973 roku, jak $i$ od tekstu oryginału. Ich odmienność została pokazana $w$ artykule dzięki szczegółowej $i$ wielofazowej analizie - najpierw samego oryginatu, potem ttumaczenia Norwidowego wiersza dokonanego przez Pawła Brodowskiego, następnie zaś wykonania wspomnianego przekładu przez Niemena na winylowej płycie 'Ode to Venus”, które porównano z wcześniejszym nagraniem utworu Norwida na albumie Niemen vol. 2. Teksty oryginatu i przekładu zbadano i zestawiono za pomoca metody kateny, natomiast ich muzyczne wykonania przy użyciu praw i zasad Petera Lowa, Johana Franzona i Andrew Kelly'ego.
\end{abstract}

Słowa kluczowe: Norwid; Niemen, „Marionetki”, tłumaczenie słów do muzyki, Brodowski

\section{Abstract}

Cyprian Norwid's Marionettes and its Polish and English Interpretations in Czesław Niemen's Musical Performance

Czesław Niemen's English interpretation of "Marionettes" differs both from his 1973 Polish version and the original text. The differences of the two renditions of Cyprian Norwid's poem are demonstrated in the article by means of a detailed and multiphase analysis - first of the original poem, then of Pawet Brodowski's translation, then finally, of Niemen's performance of this translation on his album "Ode to Venus," which is in turn compared to his earlier Polish recording of Norwid's text on the album "Niemen vol. 2." The original and translated texts are analysed and compared using the katena method, while their musical performances are assessed using Peter Low, Johan Franzon and Andrew Kelly's laws and rules governing the translation of lyrics set to music.

Key words: Norwid; Niemen, "Marionettes," translating lyrics to music, Brodowski. 


\section{Wstęp}

\section{Marionetki}

I

Jak się nie nudzić? gdy oto nad globem

Milion gwiazd cichych się świeci,

A każda innym jaśnieje sposobem,

A wszystko stoi - i leci...

II

I ziemia stoi - i wieków otchłanie,

I wszyscy żywi w tej chwili,

Z których i jednej kostki nie zostanie,

Choć będą ludzie, jak byli...

III

Jak się nie nudzić na scenie tak małéj,

Tak niemistrzowsko zrobionéj,

Gdzie wszystkie wszystkich Ideały grały,

A teatr życiem płacony -

IV

Doprawdy, nie wiem, jak tu chwilę dobić,

Nudy mię biorą najszczersze;

Co by tu na to, proszę Pani, zrobić,

Czy pisać prozę, czy wiersze - ?

$\mathrm{V}$

Czy nic nie pisać... tylko w słońca blasku

Siąść czytać romans ciekawy:

Co pisał Potop na ziarneczkach piasku,

Pewno dla ludzkiej zabawy (!) -

VI

Lub jeszcze lepiej - znam dzielniejszy sposób

Przeciw tej nudzie przeklętéj:

Zapomnieć ludzi, a bywać u osób

- Krawat mieć ślicznie zapięty...!

1861

(Norwid 1971: t. 1, 345)

W literaturze przedmiotu zaskakuje brak pełnych interpretacji regularnego metrycznie wiersza Norwida Marionetki ${ }^{1}$, złożonego z sześciu kwartyn o naprzemiennej liczbie sylab w wersach $(11+8+11+8)$ i przeplatających się rymach żeńskich. Jedyne w miarę wyczerpujące odczytanie utworu zaproponował Piotr Chlebowski (2017: 79-82), inni badacze twórczości poety wspominają o Marionetkach niejako na marginesie, przy okazji ilustrowania jakiejś cechy poetyki Norwida. Z tych „okruchów i złomków” można jednak stworzyć hierarchię cech, które stanowią o tożsamości tego utworu i powinny zostać ocalone w jego tłumaczeniu. Tym

\footnotetext{
${ }^{1}$ Bibliografia interpretacji wierszy Cypriana Norwida (Cedro, Chlebowski, Fert 2001: 28) wymienia tylko następującą pozycję: Kołoniecki 1933: 834-835.
} 
samym można więc będzie posłużyć się metodą kateny (Brajerska-Mazur 2002: 8-13; 2005: 16-18; 2012: 17-21), polegającą na zestawianiu najważniejszych interpretacji i komentarzy do tekstu wyjściowego w celu wyłonienia jego najbardziej istotnych cech strukturalnosemantycznych. Metoda ta sumuje ogólną wiedzę badaczy danego utworu - stąd nie tylko pozwala na jego jak najszerszy ogląd, ale także chroni od subiektywizmu.

\section{Analiza wiersza Norwida, jego przekładu i muzycznych interpretacji}

\subsection{Marionetki - katena}

W komentarzu do wiersza Juliusz Wiktor Gomulicki (Norwid 1966: t. 2, 626-627) wskazuje na jego dwa źródła:

Lektura drugiego wydania Les Fleurs du Mal Baudelaire'a [...] oraz refleksje na temat szeroko omawianej w prasie paryskiej nowej komety - oto prawdopodobnie dwa bodźce, które popchnęły Norwida do napisania Marionetek, będących swego rodzaju odpowiedzią na Baudelaire'owską „wszech-nudę” (jakby się wyraził poeta), której motyw wędruje przez cały zbiór Kwiatów.

Gomulicki eksponuje przewodni motyw utworu - tj. „nudę”, który został podjęty i najszerzej omówiony przez Wiesława Rzońcę (1988: 69-88). Według badacza żywiołem Norwida jest nuda pozytywna, która w twórczości poety m.in. bywa „,narzędziem dyskretnej manifestacji indywidualizmu" (1988: 82). Natomiast Piotr Chlebowski z obecnych w Marionetkach motywów inercji, apatii i właśnie nudy wyprowadza motyw czasu, którego zaburzona struktura „nie ulega bynajmniej rozpadowi, lecz odwrotnie: zagęszcza się i spowalnia” (2017: 81). Jego zdaniem konflikt pokazany w Marionetkach budowany jest „na linii rzeczywistość podmiot nudy" (2017: 82). W relacji człowiek - świat nastąpiło rozłamanie i pęknięcie, pokazane w wierszu poprzez cały szereg przeciwstawnych skojarzeń: „bezmierne momentalne, chwilowe - nieustanne, mierzalne - niemierzalne, radykalne - powolne, jednostkowe - niezmierzone, zmienne - niezmienne [...] proza - wiersz, pisanie - czytanie, biblijny Potop - ziarnko piasku" (2017: 81-82). Do tego zestawu trzeba by dodać jeszcze jedno skojarzenie (moim zdaniem w Marionetkach najważniejsze i stanowiące pointę utworu) - mianowicie: ludzie / osoby. Pozornie niesprzęgające opozycyjnych znaczeń w świetle utworu nabiera ono bowiem sensów sobie przeciwstawnych.

Według Michała Głowińskiego (1973: 105) wszystkie kontrasty znaczeniowe są w tym wierszu „bez porównania ważniejsze od swobodnej gry wyobraźni”, ponieważ tworzą 
sugestywną wizję, w której „w relację o świecie współczesnej poecie codzienności w jej wymiarze [...] salonowym wprowadza Norwid perspektywę mitologiczną, eschatologiczną czy kosmiczną".

Wspomniana przez Głowińskiego codzienność poety to oczywiście salon. Słuszny jest sąd Kazimierza Wyki (1948: 93), iż „Norwid był poetą salonu. Jako zjawisko zarazem estetyczne i psychologiczne, salon go obchodził, ciekawił i wciągał”. Jednakże w Norwidowych opisach salonu na plan pierwszy zawsze wysuwa się jego krytyka (Trznadel 1978: 252-253, 266-269) - krytyka nie tylko jałowości salonowych komeraży i pustych rozmów (jak w utworach Ostatni despotyzm, Dobra-wola), ale także... „nudy”. Składające się na nią: bezduszność, powtarzalność i czczość sztywnych konwencji towarzyskich sprawiają, że ludzie ukazani w Marionetkach noszą maski (Sławińska 1964: 33). Stają się tytułowymi marionetkami, podporządkowanymi regułom społecznym, które „fałszują ich autentyczne człowieczeństwo" (Świontek 1971: 39). Z ludzi przeistaczają się w aktorów, a świat sprowadzają do drugorzędnego teatru, do „małej i niemistrzowsko zrobionej sceny”, gdzie wszystko się powtarza, pomniejsza, deprecjonuje i... nudzi.

Bronią Norwida i przeciw „tej nudzie przeklętej”, i przeciw salonowi jest ironia. Pozorne utożsamienie się poety ze szczerze znudzonym bohaterem lirycznym wiersza i jego sposobami na „dobicie chwili” stanowi nie tylko kpiącą krytykę salonowego życia, ale także w jakiś sposób wznosi Norwida ponad nie, jest, przywołajmy tu raz jeszcze zdanie Rzońcy, „narzędziem dyskretnej manifestacji indywidualizmu” poety. Stefan Kołaczkowski (1933: 59) opisał ten proces w następujący sposób:

Czym dla Sokratesa była szermierka w szkole sofistów, tym dla światowca-Norwida był salon. Ironia posiadała ten nieoceniony na gruncie towarzyskim walor, że pozwalała mu przeciwstawić się bez ujawniania walki, bez pedanterii i powagi. Przeciwnie, odosabniał się arystokratycznie w formie gry, czyniącej go oryginalnym, przyjemnym - un homme spirituel. Dawała mu ona nieujawnione poczucie wyższości, wznosiła go ponad towarzystwo, choć z nim przestawał. [...] służyć może za kokieterię, dyskretne ujawnianie swej wyższości.

Ironia użyta przez Norwida w Marionetkach staje się jednak coraz bardziej oczywista w każdej strofie wiersza i nabiera coraz większej intensywności aż do ostatniej zwrotki. Sama pointa utworu: „Zapomnieć ludzi, a bywać u osób / - Krawat mieć ślicznie zapięty...!” stanowi przecież gorzką, i już bardzo jawną, ironiczną konstatację o grze pozorów i salonowej ułudy dehumanizującej swoich uczestników. Wyrazisty sens zakończenia, gdzie Norwid 
przeciwstawia pozytywnie wartościowanych „ludzi” negatywnie wartościowanym „osobom”2 - ukazuje Norwida jako poetę otwartej i niczym już niezawoalowanej ironii.

Wszystkie zauważone przez badaczy cechy Norwidowego tekstu stanowią o tożsamości utworu i tym samym powinny być zachowane w tłumaczeniu zakładającym wierność wobec oryginału. Zebrane w punktach (jak nakazuje katena) przedstawiają się następująco:

Wskazująca na zatratę wartości i człowieczeństwa krytyka salonowej nudy, sztucznych konwenansów i gry pozorów osiągnięta przez:

- Coraz bardziej otwartą ironię,

- Spajający utwór motyw nudy,

- Podkreślający sztuczność konwencji oraz ich redukcyjny charakter motyw teatru,

- Zestawienie przeciwstawnych skojarzeń,

- Przeciwstawienie „ludzi” i „osób”, które w kontekście wiersza nabierają kolejno pozytywnych i negatywnych konotacji,

- Regularna budowa utworu.

\subsection{Marionetki w polskojęzycznym wykonaniu Czesława Niemena}

Norwidowe Marionetki były tłumaczone na język angielski co najmniej dziesięciokrotnie (Brajerska-Mazur 1999-2000: 385-393; Brajerska-Mazur 2007: 387-391)³, w tym przez Pawła Brodowskiego do muzyki Czesława Niemena (1973). Jest to bardzo specyficzna wersja oryginału, wymagająca szczególnej uwagi badacza, bowiem stanowi nie tylko przekład słów do muzyki (rządzący się odmiennymi prawami od tłumaczenia stricte literackiego), ale jest także swoistą interpretacją pierwowzoru, który po raz pierwszy został wykonany przez Niemena na polskojęzycznej płycie Niemen vol. $2^{4}$, funkcjonującej w wersji kompaktowej pod nazwą Marionetki ${ }^{5}$.

\footnotetext{
${ }^{2}$ W kontekście wiersza rozumianym jako: „osobniki z rodzaju Homo sapiens”, nie wykazujące „,prawdziwego człowieczeństwa, które powinno mieć w sobie coś boskiego" (Gomulicki 1966: 627).

${ }^{3}$ Zestawienia te trzeba uzupełnić o: Borchardt 2011: 121-123.

${ }^{4}$ Niemen vol. 2 (1973), Wydawca: Polskie Nagrania Muza, Winyl, LP, Album, XL 0896 (istnieją również 3 inne wersje tej płyty winylowej wydane w 1973 roku w Polsce: SX 0896, SXL 0896, SXL 0896).

${ }^{5}$ Marionetki (1994), Wydawca: Digiton, CD, Comp., DIG 130 (istnieje również 7 innych wersji tej płyty kompaktowej, ostatnia z 2017 roku, Wydawca: Polskie Nagrania Muza, 019029580194 6).
} 
Polskojęzyczne wykonanie Norwidowego wiersza ${ }^{6}$ przez Niemena bardzo trafnie opisał Chlebowski (2017: 82-88), podkreślając w swojej analizie następujące cechy tej kompozycji:

- muzyczną ascezę,

- wykonanie wbrew stroficznemu porządkowi wiersza, a $\mathrm{w}$ zgodzie $\mathrm{z}$ jego semantycznym oraz ideowym przesłaniem,

- eksponowanie partii wokalnej kosztem instrumentalnej warstwy utworu,

- rezygnację z rytmu,

- finezyjne balansowanie wokalu między tradycyjnym śpiewem a deklamacją,

- swobodę i zmienność,

- sytuacyjne i semantyczne traktowanie tekstu,

- tłumienie muzycznego ruchu na rzecz dźwiękowej barwy.

Według Chlebowskiego (2017: 85-86):

Skłonność do teatralizacji, ujawniająca się w redukcji instrumentarium oraz jego funkcji, a także specyficznym traktowaniu wokalu, $\mathrm{z}$ tendencją do deklamacji ma bez wątpienia swój semantyczny walor - w ten sposób Niemen dąży do uwypuklenia określonych miejsc tekstu. Zwraca uwagę przede wszystkim podkreślaniem motywów scenicznych i teatralnych, co ma bez wątpienia związek z zasadniczym tematem wiersza oraz z zespołem motywów wypełniających jego poetycką przestrzeń.

Wspomniane motywy to „metafora świata teatru”, krytyka salonu oraz wszechobecna w wierszu ironia. Najważniejszy rys Niemenowej interpretacji tekstu Norwida to dystans, niejednoznaczność i niepewność co do przedstawianych treści, przejawiający się w rezerwie do obecnych $\mathrm{w}$ wierszu przeciwieństw. Zdaniem badacza $\mathrm{w}$ wykonaniu Niemena $\mathrm{np}$.: „odczucie niezwykłości i ogromu wszechświata, bo 'milion gwiazd cichych się świeci', nie przekreśla doświadczenia pustki”' (2017: 87).

Anglojęzyczna wersja Marionetek jest jednak odmienna od swojego polskojęzycznego pierwowzoru z 1973 roku$^{7}$. Zatem, by przekonać się o różnicach między obiema wersjami utworu Norwida zaproponowanymi przez Niemena, należy poddać szczegółowej analizie

\footnotetext{
${ }^{6}$ Marionetki zostały nagrane i wydane w 1973 roku przez grupę Niemen (w składzie: Czesław Niemen, Helmut Nadolski oraz muzycy z grupy SBB: Józef Skrzek, Anthimos Apostolis, Jerzy Piotrowski oraz trębacz Andrzej Przybylski) na stronie A LP Niemen vol. 2.

${ }^{7}$ CD Ode to Venus z 2003 roku opatrzone jest taką oto informacją: „Track 2 (Puppets) is a different and an English language version of Niemen's Vol. 2. LP (1973) A1 song entitled Marionetki (Puppets)" [Ścieżka 2 (Puppets) jest inną anglojęzyczną wersją piosenki Marionetki (Puppets) ze strony A1 płyty długogrającej Niemen vol. 2 (1973)].
} 
najpierw tłumaczenie Norwidowego wiersza dokonane przez Brodowskiego, potem zaś jego Niemenowskie wykonanie z winylowej płyty Ode to $\operatorname{Venus}^{8}$ i porównać je z wcześniejszym nagraniem tekstu Norwida z albumu Niemen vol. 2. W badaniu przekładu Norwidowego tekstu pomogą cechy zebrane i zhierarchizowane podczas przeprowadzonej powyżej analizy oryginału, który w metodzie kateny jest zawsze głównym punktem odniesienia naukowej refleksji i badawczego pochylenia nad tłumaczeniem (Brajerska-Mazur 2011: 27-34; Puzynina 2014: 183-187).

\subsection{Marionetki w tłumaczeniu Pawła Brodowskiego}

\section{Puppets}

Music: Cz. Niemen

Słowa: C. Norwid / thum.: Paweł Brodowski

Nagranie z płyty: Ode to Venus, wyd. NRF, GB 1973

I

How can't you be bored? When there above the globe

A million silent stars are shining

And each in its own different way

And all the things standing - and flying...

II

The Earth is standing - and abbys of ages

And all now alive and seen,

Won't leave a trace on merciless pages

Though people will be as they've been

III

How can't you be bored on so small a stage,

So unmasterly made

Where all the Ideals took part in a play

And theatre bill human life paid

IV

How can you make moment pass

I'm tired and bored to tears;

What can you do to stop this farce

Shall I write prose or verse - ?

$\mathrm{V}$

Or even better - there's a braver way

To change this course of fate:

Forget about people and go out each day

- With a tie beautifully straight... !

\footnotetext{
${ }^{8}$ Ode to Venus, wyd. NRF, GB 1973. CBS - S 65 606, CBS - S 65606, Vinyl, LP, Album.
} 
Nawet bardzo pobieżna lektura przytoczonego przekładu z Ode to Venus uwidacznia, iż jest on krótszy i mniej regularny niż polskojęzyczny oryginał. Brodowski nie przetłumaczył piątej strofy wiersza i nie utrzymał równej liczby sylab w jego naprzemiennych wersach, zachował natomiast większość rymów. Głębsze wczytanie się w tę wersję Marionetek dowodzi natomiast, iż tłumacz zamienił w niej Norwidową krytykę salonu na opowieść o bezwolności i małości ludzi wobec sił kosmosu. Bezsilność „Marionetek” na tle egzystencjalno-kosmicznej perspektywy (Radoszewski 2004: 102) najwyraźniej ilustruje czwarta strofa przekładu, w której znudzenie osoby mówiącej zostało nie tylko podkreślone, ale także przyrównane do farsy:

Tabela 1. Czwarta strofa wiersza w thumaczeniu Brodowskiego i we wtórnej translacji.

\begin{tabular}{|c|c|c|}
\hline Norwid & Brodowski & backtranslation \\
\hline $\begin{array}{l}\text { Doprawdy, nie wiem, jak tu } \\
\text { chwilę dobić, } \\
\text { Nudy mię biorą najszczersze; } \\
\text { Co by tu na to, proszę Pani, } \\
\text { zrobić, } \\
\text { Czy pisać prozę, czy wiersze - ? }\end{array}$ & $\begin{array}{l}\text { How can you make moment } \\
\text { pass } \\
\text { I'm tired and bored to tears; } \\
\text { What can you do to stop this } \\
\text { farce } \\
\text { Shall I write prose or verse - ? }\end{array}$ & $\begin{array}{l}\text { Jak można sprawić, by minęła } \\
\text { chwila } \\
\text { Jestem znudzony i zmęczony do } \\
\text { łez; } \\
\text { Jak można powstrzymać tę farsę } \\
\text { Mam pisać prozę, czy poezję - ? }\end{array}$ \\
\hline
\end{tabular}

W tej strofie przeciwstawienie ,proza - wiersze” zostało zachowane, lecz w całym przekładzie Brodowskiego opozycyjnych zestawień jest ogólnie mniej niż w oryginale i wydobywają one egzystencjalno-kosmiczną perspektywę wiersza. Porównanie „chwilowe - nieustanne” W drugiej strofie przekładu przybrało np. inną postać niż w pierwowzorze, w którym przemijanie zostało zilustrowane obrazem całkowitej anihilacji ludzi („I wszyscy żywi w tej chwili, / Z których i jednej kostki nie zostanie”). W przekładzie tymczasem jest mowa o „niezostawianiu śladów na bezlitosnych stronach” („,And all now alive and seen, / Won't leave a trace on merciless pages"), co oddaje ogólny sens oryginału, ale przedstawia wizję świata z dystansu, z punktu widzenia uniwersum. Co więcej, z tłumaczenia Brodowskiego zniknęło zupełnie najważniejsze w utworze przeciwstawienie - mianowicie: „ludzie / osoby”. Zresztą, perspektywa całej ostatniej strofy przekładu jest zmieniona w stosunku do bardziej skupionego na człowieku oryginału:

Tabela 2. Ostatnia strofa wiersza w thumaczeniu Brodowskiego i we wtórnej translacji.

\begin{tabular}{|l|l|l|}
\hline Norwid & Brodowski & backtranslation \\
\hline
\end{tabular}




\begin{tabular}{|l|l|l|}
\hline Lub jeszcze lepiej - znam & Or even better - there's a braver & Lub jeszcze lepiej - znam \\
dzielniejszy sposób & way & dzielniejszy sposób \\
Przeciw tej nudzie & To change this course of fate: & By zmienić ten bieg losu: \\
przeklętéj: & Forget about people and go out & Zapomnieć ludzi i wychodzić \\
Zapomnieć ludzi, a bywać & each day & każdego dnia \\
u osób & - With a tie beautifully straight... & Z pięknie wyrównanym \\
- Krawat mieć ślicznie & $!$ & krawatem...! \\
zapięty...! & &
\end{tabular}

U Brodowskiego w miejscu „nudy przeklętej” widnieje „bieg losu”, a pozytywnie wartościowanym „ludziom” zostało przeciwstawione bezosobowe..., „wychodzenie na miasto” (składanie wizyty?). Tym samym w jego wersji tekstu Norwida kluczowy motyw utworu - tj. nuda został sprowadzony na inną płaszczyznę niż $w$ oryginale: nie wynika $z$ konwencji towarzyskich, ale jest zrządzeniem opatrzności, siłą wyższą, której skutek - tj. odczłowieczenie bywalców salonu nie jest tak wyraźnie i dobitnie sformułowany jak w pierwowzorze.

W porównaniu z innymi przekładami zakończenia wiersza Norwida przekład Brodowskiego jest najbardziej zmieniony i jednocześnie najmniej ze wszystkich Norwidowski. Pozostali thumacze Marionetek przeciwstawili: „ludzi” i „społeczeństwo” (Michael 1944: 185), „ludzi” i „osobistości” (Brooke-Rose 1958: 196-197), „ludzi” i „osoby” (Czerniawski 1986: 27, 2004: 43), bądź też „ludzi” i „celebrytów” (Borchardt 2011: 123). Zawsze jednak, po Norwidowsku, stosowali rozróżnienie na dwie grupy - tę traktowaną z respektem i tę zdehumanizowaną poprzez towarzyskie konwenanse:

Norwid:

Zapomnieć ludzi, a bywać u osób

- Krawat mieć ślicznie zapięty...!

1861

Michael:

to forget people and go out in society-to have a tie that is beautifully tied...!

Brooke-Rose:

$[\ldots]$ to pass people by

But visit personages - and display

An exquisitely knotted tie...!

Czerniawski ${ }^{9}$ :

Forget p e o p l e, make calls on p e r s o n s,

Wear a neatly fastened tie! ...

9 W wydaniach z 1988 i 2004: people i persons. 
Borchardt:

Forget people, visit grandees,

- Keep my tie neatly fastened!...

Również wszyscy tłumacze wiersza Norwida poza Brodowskim przełożyli tytuł utworu jako Marionettes (marionetki). Puppets Brodowskiego to jeszcze bardziej podatne na manipulację pacynki - także oddające ogólny wydźwięk tekstu (życie to teatr), jednakże, poprzez skojarzenie kukiełek z przedstawieniem dla dzieci, zmieniające metaforę teatru i czyniące jednocześnie Norwidowską ironię bardziej gorzką. Ludzie, sprowadzeni tu do pacynek uzależnionych od zrządzenia losu, zdają się jeszcze bardziej niż w oryginale bezwolni i ulegli, lecz już nie wobec towarzyskich konwenansów, ale wobec kolei życia.

Mając na uwadze cechy, które (jak wykazała katena) stanowią o tożsamości polskiego oryginału można więc stwierdzić, że w przekładzie Brodowskiego wystąpiło kilka przesunięć strukturalno-znaczeniowych. Tłumacz zmienił w nim motyw teatru, uwypuklając jego związek z farsą i przedstawieniem kukiełkowym, natomiast spajający utwór motyw nudy przeniósł na płaszczyznę doli ludzkiej uzależnionej od sił wyższych. Ocalił charakterystyczną dla Marionetek ironię, lecz ta $\mathrm{w}$ jego przekładzie staje się bardziej gorzka i nie nabiera coraz większej otwartości, ponieważ zabrakło w nim wyraźnego zestawienia przeciwstawionych sobie „ludzi” i „osób”. Inne sprzężenia opozycyjnych znaczeń zostały w tłumaczeniu zachowane, lecz i one przesuwają perspektywę utworu $\mathrm{z}$ salonowej na kosmiczną $\mathrm{i}$ uwypuklają bezsilność człowieka wobec zimnych sił wszechświata. Regularna budowa Norwidowego wiersza również nie ocalała w pełni, bowiem w anglojęzycznej wersji zostały oddane naprzemienne rymy, ale straciła na regularności przeplatająca się liczba sylab w wersach $(11+8+11+8)$.

\subsection{Marionetki w tlumaczeniu do muzyki}

Trzeba jednakże pamiętać, że Brodowski tłumaczył słowa do muzyki, musiał więc przestrzegać innych zasad niż te rządzące sztuką przekładu literackiego. Reguły, które powinien mieć na względzie to przede wszystkim: Trzy Kroki Petera Lowa (2003: 87-103), Pięć Zasad Johana Franzona (2014: 373-400), Pentatlon Lowa (2005: 185-212) oraz prawa ustalone przez Andrew Kelly'ego (1987: 25-34). Te ostatnie nakazują tłumaczom tekstów do muzyki, by oddali:

1. rytm śpiewanego tekstu;

2. jego znaczenie;

3. jego styl; 
4. rymy

5. i brzmienie.

6. Poważali zakładanych odbiorców przekładu

7. oraz szanowali oryginał.

Przekład Brodowskiego nie zawsze przestrzega powyższych praw. Przesuwa znaczenie oryginału tym samym nie we wszystkim go szanuje. Nie zawsze poważa również zakładanych odbiorców tłumaczenia i Niemenowskiej twórczości (w Polsce przyzwyczajonych do utworów głębokich i wymagających uwagi), ponieważ zmieniając tekst upraszcza go i przesuwa na inną (współcześnie być może bardziej zrozumiałą) płaszczyznę. Należy podkreślić, że nie jest to w żadnym razie perspektywa Norwidowska - ten „chrześcijański myśliciel” (Czaykowski 2004: 7-19; Dunajski 1985, 1996; Merdas 1983; Sawicki 1994: 241-254) nie stworzyłby utworu wyrażającego niemoc ludzi wobec Fatum ${ }^{10}$.

Pięć Zasad Johana Franzona dotyczy podstawowej kwestii - tj. rozróżnienia między ważnością tekstu i muzyki w przekładzie. W zależności od rangi, jaką się przykłada do któregoś z tych elementów można:

1. Zostawić słowa piosenki bez tłumaczenia,

2. Przekładać słowa nie licząc się z muzyką,

3. Stworzyć nowy tekst do muzyki, pozostawiając ogólny sens pierwowzoru (najczęściej stosowana metoda),

4. Skomponować nową muzykę do słów wiernie oddających znaczenie oryginału (najrzadziej stosowna metoda),

5. Dopasować przekład do linii melodycznej, by można było zaśpiewać piosenkę.

Wydaje się, że w przypadku Marionetek Norwida, i dla Brodowskiego, i dla Niemena, najważniejsze były słowa, potem dopiero melodia (która została, jak wykażę później, trochę zmieniona i dopasowana do tekstu przekładu). Z drugiej jednak strony, znaczenie oryginału nie zostało oddane $\mathrm{w}$ przekładzie wiernie, można więc jedynie stwierdzić, iż tłumaczenie $\mathrm{z}$ Ode to Venus oscyluje gdzieś pomiędzy drugą i czwartą zasadą Franzona (tj. pozostawia ogólny sens pierwowzoru i dopasowuje do niego muzykę).

Według Petera Lowa przekładając słowa do muzyki należy przede wszystkim:

1. Zidentyfikować dominantę tekstu,

${ }^{10}$ Obszerna literatura przedmiotu [W:] Cedro, Chlebowski, Fert 2001: 17-18; Nowak 1991-1992: 126; BrajerskaMazur 2002: 71-102. 
2. Ustalić priorytety przekładu,

3. Podjąć decyzję co do zachowania rymów.

Jego Pentatlon natomiast wskazuje na pięć cech, które powinny być brane pod uwagę przez tłumaczy tekstów śpiewanych. Są to mianowicie: śpiewalność, rytm, rym, sens i naturalność danego tekstu w przekładzie do muzyki.

Oceniając tłumaczenie Brodowskiego według zasad Lowa można stwierdzić, że dominantą Marionetek był dla niego motyw teatru, pojęty jako bezwolność i bezsilność ludzi/kukiełek wobec sił kosmosu i zrządzenia losu. Za priorytet przekładu tłumacz uznał przekazanie ogólnego sensu utworu - tj. „obojętności na ludzkie losy” (Radoszewski 2004: 102), lecz nie wyrażony poprzez krytykę salonu, ale pokazanie wielkości zimnego wszechświata (,When there above the globe / A million silent stars are shining”, „The Earth is standing - and abbys of ages”, „merciless pages”, „so small a stage”). Jego decyzja co do zachowania rymów była pozytywna, co może dziwić, ponieważ Brodowski jako bliski współpracownik Niemena ${ }^{11}$ wiedział, iż muzyk śpiewając poezję zawsze sprzeciwiał się metrycznym rygorom regularnych struktur wierszowych (Chlebowski 2017: 25-35).

Tłumacz dość wiernie przestrzegał reguł wymienionych w Pentatlonie Lowa, a w jego wersji zwraca uwagę zachowanie ogólnego sensu, rymów i śpiewalności Norwidowego wiersza. W poczuciu naturalności tekstu przeszkadzają obecne w przekładzie błędy językowe („How can’t you be bored?”, „And theatre bill human life paid”, rodzajniki), nawet jeśli się weźmie pod uwagę fakt, iż teksty piosenek bywają w języku angielskim niegramatyczne ${ }^{12}$.

\subsection{Marionetki w anglojęzycznym wykonaniu Czesława Niemena. Wnioski}

Czesław Niemen zaśpiewał Puppets jako drugi utwór na płycie Ode to Venus. Jest on o 24 sekundy dłuższy (4:34) od polskojęzycznej wersji z albumu Niemen vol. 2 (4:10). Różnice między tymi dwoma wykonaniami zasadzają się głównie na ich innej instrumentalizacji, co do podejścia do samego utworu i wydobycia z niego ważnych dla muzyka treści nie widać jednak znaczących odmienności (choć tu, z uwagi na sam tekst przekładu, obojętność na ludzkie losy została pokazana nie z perspektywy salonu, ale kosmosu). Anglojęzycznemu przekładowi Marionetek Norwida nie towarzyszy już trąbka (Andrzej Przybielski) i talerze (Helmut

\footnotetext{
${ }^{11}$ Brodowski był członkiem zespołu „Akwarele”, towarzyszącego Niemenowi od chwili powstania (1966) do momentu rozwiązania (1969) we wszystkich nagraniach, trasach koncertowych i festiwalach w kraju i za granicą. Nagrał z Czesławem Niemenem płytę "Dziwny jest ten świat" w 1967 roku. Zob. http://www.bibliotekapiosenki.pl/zespoly/Akwarele; $\quad$ http://muzyka.onet.pl/rock/brodowski-niemen-bylcharyzmatyczna-postacia/jdyj8; http://www.newsweek.pl/kultura/czeslaw-niemen-biografia-kariera-akwarelemuzyka-rozrywka-newsweek-pl,artykuly,281791,1.html.

${ }^{12}$ Zob. https://hooksandharmony.com/20-songs-bad-grammar/
} 
Nadolski) - utwór jest więc jeszcze bardziej ascetyczny niż tekst zaśpiewany przez Niemena na polskiej płycie. Muzyk, tak jak poprzednio, wykonał kompozycję wbrew stroficznemu porządkowi wiersza, tym samym $\mathrm{w}$ jego realizacji nie słychać rymów oddanych przez Brodowskiego, natomiast zostaje wydobyte ideowe przesłanie tekstu. Najważniejszy jest wokal Niemena, któremu towarzyszy jedyny w tym wykonaniu beat - tj. uderzanie w klawisze elektrycznego pianina. Beat ten wydobywa ważne dla Niemena treści, które muzyk oddaje balansując między deklamacją a śpiewem. Tak jak na płycie Niemen vol. 2, i tu kompozycja została podzielona na dwie nierówne części, ,przy czym część pierwsza [...] obejmuje swym zasięgiem wyłącznie strofę pierwszą tekstu (i trwa minutę i piętnaście sekund), druga zaś, [...] niemal dwu i pół minutowa - obejmuje strofy pozostałe. Punkt ciężkości artysta przesuwa tu na partię wokalną" (Chlebowski 2017: 82-83) ${ }^{13}$. Całość charakteryzuje swoboda i zmienność wykonania, w którym „dźwięki poruszają się w różnych skalach i wymiarach: raz są krótkie, by za chwilę przejść w długie i przeciągnięte frazy; bywają zamknięte, o barwie mrocznej, a innym znów razem otwarte i pełne, o wyraźniej jaśniejszym i efektowniejszym modelunku, by w końcówce odcinka wejść w harmoniczną relację z niską przeciągniętą pedałową nutą (ściśle dwoma nutami) organów" (Chlebowski 2017: 83). Poprzez wokal i akcentowanie poszczególnych słów (tu przecież inaczej znaczących, inaczej brzmiących i czasem umiejscowionych $\mathrm{w}$ innym niż $\mathrm{w}$ oryginale miejscu $\mathrm{w}$ wersie) Niemen, odwrotnie niż $\mathrm{w}$ poprzednim wykonaniu, nie uwypukla i nie wydobywa z wiersza krytyki salonu:

Marionetki to przecież mistrzowski obraz salonowej nudy, a ogólniej - obojętności na ludzkie losy, w którym, jak w mikroskopijnym zbliżeniu Norwid przechodzi od egzystencjalnokosmicznej perspektywy do demaskatorskiej moralnej puenty, podszytej melancholijną ironią („Mam dzielniejszy sposób / przeciw tej nudzie, przeklętej, / Zapomnieć ludzi, a bywać u osób”) .

(Radoszewski 2004: 102).

W anglojęzycznej wersji utworu Norwida zaśpiewanego przez Niemena przez cały czas dominuje egzystencjalno-kosmiczna perspektywa, której dotyczy także demaskatorska moralna puenta.

Podobnie jak na polskojęzycznej płycie muzyk demonstruje dystans do kontrastów, które w tłumaczeniu uległy już przecież zredukowaniu i złagodzeniu. Na Ode to Venus całość wykonania jest ponadto bardziej ascetyczna i stonowana ze względu na prostszą niż w polskiej wersji językowej aranżację muzyczną oraz samo zmienione w stosunku do oryginału

${ }^{13} \mathrm{U}$ Chlebowskiego, piszącego o polskojęzycznym wykonaniu Marionetek, jest: „,i trwa minutę i pięćdziesiąt sekund)". 
tłumaczenie Brodowskiego. Akcentując te same miejsca w tekście śpiewanym Niemen uwypukla tu przecież inne motywy sceniczne i teatralne niż w oryginale, posługuje się inaczej skonstruowaną ironią, a krytykę salonu zamienia na krytykę losu. Te uproszczenia i przesunięcia znaczeniowe są $\mathrm{w}$ znacznej mierze wynikiem decyzji tłumacza, które - ujęte w prawa i zasady Lowa, Franzona i Kelly'ego - pokazują jego preferencje do przedkładania pewnych aspektów przekładu słów do muzyki nad inne (przypomnijmy: styl, rytm i brzmienie ważniejsze od szacunku dla odbiorców oraz oryginału; pozostawić ogólny sens pierwowzoru i dopasować do niego muzykę; zachować rymy; wydobyć śpiewalność tekstu). W rezultacie słuchając anglojęzycznych Marionetek odbiorca dostaje porcję wysokiej klasy poezji, muzyki i śpiewu, znacznie jednak uproszczonych (zwłaszcza pod względem przesłania) w stosunku do swojej pierwotnej wersji z polskiej płyty Niemena, która sama w sobie także już była swoistą interpretacją oryginału.

\section{Bibliografia}

Borchardt, Danuta in collaboration with Agata Brajerska-Mazur (2011) Cyprian Norwid. Poems. New York: Archipelago Books.

Brajerska-Mazur, Agata (1999-2000) „Bibliografia przekładów utworów Norwida na język angielski”. Studia Norwidiana, 17-18/1999-2000; 385-393.

Brajerska-Mazur, Agata (2002) O angielskich ttumaczeniach utworów Norwida. Lublin: TN KUL.

Brajerska-Mazur, Agata (2005) „Katena and Translations of Literary Masterpieces.” Babel, 51/2005; 16-30.

Brajerska-Mazur, Agata (2007) „Bibliografia przekładów utworów Norwida na język angielski II”. Studia Norwidiana, 24-25/2007; 387-391.

Brajerska-Mazur, Agata (2011) „Katena a przekład współczesnej poezji polskiej”. [W:] Anna Kukułka-Wojtasik (red) Translatio i literatura. Warszawa: UW; 27-34.

Brajerska-Mazur, Agata (2012) Filutka z filigranu paraduje w cudzym losie. Lublin: Wydawnictwo KUL.

Brodowski, Paweł (1973) płyta Niemena Ode to Venus (1973), wyd. NRF, GB 1973, Winyl, LP, Album, CBS - S 65 606, CBS - S 65606.

Brooke-Rose, Christine (1958) „Cyprian Norwid. Twelve Poems”. Botteghe Oscure, 22/1958; 191-199. 
Cedro, Adam, Piotr Chlebowski, Józef Fert (2001) Bibliografia interpretacji wierszy Cypriana Norwida. Lublin: TN KUL.

Chlebowski, Piotr (2017) „Norwidowe Marionetki - Grupy Niemen”. [W:] Piotr i Edyta Chlebowscy (red.) Czesław Niemen i jego ptytowe dzieła 2. Lublin: Wydawnictwo KUL; 79-96.

Chlebowski, Piotr (2017) „Rockowa suita Niemena do wiersza Norwida”. [W:] Piotr i Edyta Chlebowscy (red.) Czesław Niemen i jego płytowe dzieła 2. Lublin: Wydawnictwo KUL; $9-40$.

Czaykowski, Bogdan (2004) "The Poet as 'Christian Socrates" [W:] Cyprian Kamil Norwid. Selected Poems. (tłum.) Adam Czerniawski. London: Anvil Press; 7-19.

Czerniawski, Adam (1986) Cyprian Kamil Norwid. Poezje/Poems. Kraków: Wydawnictwo Literackie.

Czerniawski, Adam (1988) The Burning Forest. Newcastle upon Tyne: Bloodaxe Books.

Czerniawski, Adam (2004) Cyprian Kamil Norwid. Selected Poems. London: Anvil Press.

Dunajski, Antoni (1985) Chrześcijańska interpretacja dziejów w pismach Cypriana Norwida. Lublin: RW KUL.

Dunajski, Antoni (1996) Teologiczne czytanie Norwida. Pelplin: "Bernardinum”.

Dunajski, Antoni (1996) SŁOWO stało się SIŁA. Zarys Norwidowej teologii słowa. Pelplin: "Bernardinum".

Franzon, Johan (2014) "Choices in Song Translation: Singability in Print, Subtitles and Sung Performance". [W:] The Translator, February 2014; 373-399.

Głowiński, Michał (1973) „Norwida wiersze-przypowieści”. [W:] Maria Żmigrodzka (red.) Cyprian Norwid w 150-lecie urodzin. Materiaty konferencji naukowej 23-25 września 1971. Warszawa: PIW; 72-109.

Gomulicki, Juliusz W. (1966) „Komentarz do wiersza Marionetki”. [W:] Cyprian Norwid, Dzieła zebrane, t. II: wiersze (oprac.) Juliusz Gomulicki. Warszawa: PIW; 626-627.

Kelly, Andrew (1987) “Translating French Songs as a Language Learning Activity”. British Journal of Language Teaching 25(1)/1987; 17-39.

Kołaczkowski, Stefan (1933) „Ironia Norwida”. Droga 11/1933: Pamięci Cypriana Norwida; 40-61.

Kołoniecki, Roman (1933) „Społeczne zadania literatury”. Wiedza i Życie, 1/1933; 27-39.

Low, Peter (2003) "Singable Translations of Songs". Perspectives: Studies in Translatology 11(2)/2003; 87-103. 
Low, Peter (2005) "The Pentathlon Approach to Translating Songs". [W:] Dinda L. Gorlée (red.) Song and Significance - Virtues and Vices of Vocal Translation. Amsterdam: Rodopi; 185-212.

Merdas, Alina (1983) Luk przymierza. Biblia w poezji Norwida. Lublin: RW KUL.

Michael, Maurice (1944) A Polish Anthology, compiled by T. M. Filip [Tytus Filipowicz] and translated by M. A. Michael. London: Duckworth.

Norwid, Cyprian (1971-1976) Pisma wszystkie. Zebrał, tekst ustalił, wstępem i uwagami krytycznymi opatrzył Juliusz Gomulicki, t. I-XI, Warszawa: PIW.

Nowak, Zbigniew (1991-1992) „Jeszcze jeden kontekst do Fatum Norwida”. Studia Norwidiana 1991-1992/9-10; 125-131.

Puzynina, Jadwiga (2014) „Filutka z filigranu paraduje w cudzym losie”. Roczniki Humanistyczne LXII, z. 6: językoznawstwo; 183-187.

Radoszewski, Roman (2004) Czesław Niemen. Kiedy się dziwić przestanę... Warszawa: Iskry.

Rzońca, Wiesław (1998) Witkacy-Norwid. Warszawa: Semper.

Sawicki, Stefan (1994) Wartość - sacrum - Norwid. Lublin: RW KUL.

Sławińska, Irena (1964) „Reżyserska ręka Norwida”. Przegląd Humanistyczny IV/1964; 9-37.

Świontek, Sławomir (1971) „Norwidowski teatr świata”. Pamiętnik Literacki 3/1971; 33-50.

Trznadel, Jacek (1978) Czytanie Norwida. Próby. Warszawa: PIW.

Wyka, Kazimierz (1948) Cyprian Norwid. Poeta i sztukmistrz. Kraków: Nakł. Polskiej Akademii Umiejętności. 